\title{
The Purposes of Pre-Trial Detention and the Quest for Alternatives
}

\author{
Adriano Martufi \\ Assistant Professor of Criminal Law, Faculty of Law, \\ Leiden University, Leiden, the Netherlands \\ a.martufi@law.leidenuniv.nl \\ Christina Peristeridou \\ Assistant Professor, Criminal Law \& Criminology, Maastricht University, \\ Maastricht, the Netherlands \\ c.peristeridou@maastrichtuniversity.nl
}

\begin{abstract}
In this article, we take issue with the ECHR standards on pre-trial detention. These standards are considered panacea for the reported overuse of pre-trial detention in Europe. They focus on the legitimate purposes of detention as safeguards to ensure the principle of ultima ratio. Yet these purposes are heterogeneous as pre-trial detention protects the pending proceedings but also averts risks pertinent to criminal policy. In our analysis we discuss the shortcomings of the ECHR standards to fully protect from abusive detention. Moreover, we reveal internal inconsistencies with the presumption of innocence. One major example is the use of pre-trial detention to prevent reoffending, which blurs the boundaries between custody on remand and preventive detention. Additionally, we delve deeper into the obligation to use milder measures as part of the ECHR standards, which remains superficial and vague. Conclusively, we encourage the reflection and re-examination of the ECHR standards for pre-trial detention, instead of focusing merely on their better enforcement.
\end{abstract}

\section{Keywords}

pre-trial detention - alternative measures - Article 5 ECHR - risk of absconding preventive detention - bail - presumption of innocence - ultima ratio 

Problem

Pre-trial detention has been under the spotlight during the last few years, with various empirical projects being conducted in Europe and globally. All these studies point to a problematic (over)use, which impacts negatively on a variety of individual and procedural rights, e.g. right to liberty, presumption of innocence, privilege of non-self-incrimination and access to legal advice; reportedly, lengthy detentions have far-reaching consequences regarding the economic fate and stability of families, the state and the criminal justice system. ${ }^{1}$ Statistics show that about one in four prisoners (approximately $22 \%$ of prisoners in Europe) is a pre-trial detainee. ${ }^{2}$ While the use of pre-trial detention is inflated according to these surveys, alternative measures remain underused. Alternatives to pre-trial detention are milder measures whose content varies widely across jurisdictions (spanning from unconditional freedom on remand to electronic monitoring). They are meant to offer a less strict option in dealing with the defendant pending investigation and trial. Nevertheless, courts in many jurisdictions exhibit a lack of trust in their use. ${ }^{3}$

In this article, we delve deeper into the purposes of using pre-trial detention and alternative measures. By pre-trial detention, we refer to detention on remand ordered after (and thus not including) arrest. Justifying pre-trial detention appears crucial for its rational use. Traditionally, detention on remand has been conceptualized as a utilitarian or consequentialist measure. This means that it draws its legitimacy from serving a purpose and potentially producing certain consequences. In addition, scholars argue that detention on remand must always be regarded as a risk-oriented measure: while its purposes vary across jurisdictions, they have in common the prevention of certain risks. ${ }^{4}$ The

1 W. Hammerschick, C. Morgenstern, S. Bikelis, M. Boone, I. Durnescu et al., DETOUR - Towards Pre-trial Detention as Ultima Ratio. Comparative report, (Vienna: Institut für Strafrecht, 2017); Fair Trials, A Measure of Last Resort? The practice of pre-trial detention decision making in the EU, (London: Fair Trials, 2016); Open Society Justice Initiative, Presumption of Guilt: The Global Overuse of Pretrial Detention, (New York: Open Society Justice Initiative, 2014); Open Society Justice Initiative \& UNDP, The Socioeconomic impact of pre-trial detention, (New York: Open Society Justice Initiative, 2011).

2 See M. F. Aebi, M. M. Tiago, L. Berger-Kolopp, C. Burkhardt, SPACE I - Council of Europe Annual Penal Statistics: Prison populations, (Strasbourg: Council of Europe, 2017), updated on 7 February 2019, p. 78-80, on the number of 'detainees not serving a final sentence'.

3 Fair Trials, op. cit., p. 27.

4 C. Morgenstern, Die Untersuchungshaft. Eine Untersuchung unter rechtsdogmatischen, kriminologischen, rechtsvergleichenden und europarechtlichen Aspekten, (Bade-Baden: Nomos, 2018). 
European Court of Human Rights (ECtHR) has interpreted article 5 para 1 and 3 European Convention on Human Rights (ECHR) narrowly, adding the requirement of a legitimate purpose. More specifically, pre-trial detention can be ordered exclusively when justified on the basis of legitimate public interests. ${ }^{5}$ These correspond to certain risks to be prevented, e.g. risk of absconding. This is not surprising. Pre-trial detention has long been justified as an instrument to bridge the time gap between a suspect's capture and trial, thus dealing with certain risks that may occur during this period. As we will see, however, the question as to what kind of risks justify the use of pre-trial detention remains controversial.

This risk-oriented approach can be linked to a strong principled argument. The Convention system is underpinned by the idea that detention can only be used as a measure of last resort (or principle of ultima ratio) and without violating the presumption of innocence. Article 5 ECHR sets out a general right to liberty, followed by the prohibition of locking people up save in exceptional circumstances. The requirement of legitimate purpose serves the principle of ultima ratio but also the presumption of innocence: requiring pre-trial detention to serve a specific purpose is key to avoid that deprivation of liberty is used as an 'anticipation of punishment'. As it will be discussed, however, the distinction between pre-trial detention and custodial sentencing tends to blur when pre-trial detention is used as means to prevent re-offending or, even more broadly, to protect the public order. ${ }^{6}$

At national level, there is wide consensus around the fact that pre-trial detention must have a specific aim. In this article, however, we focus on the standards devised by the ECtHR. These standards are usually regarded as a starting point when dealing with pre-trial detention in the EU. More specifically, policy documents and research surveys emphasise the need to comply with ECHR standards to reduce pre-trial detention, while securing the respect of the presumption of innocence. ${ }^{7}$ In recent case law, even the Court of Justice of the European Union (CJEU) seems to fall back - rather blindly - on the Strasbourg

5 ECtHR, 28 July 2005, Czarneckiv Poland, appl. no. 75112/01.

6 P. A. Albrecht, 'Die Untersuchungshaft - ein Straf oder Schuldspruch? Ein Pläydoyer fûr den Grundsatz der Unschuldvermutung in Haftrech' in A. Donatsch, ed., Strafrecht, Strafprozesrecht und Menschenrecthen. Festschrift für Stefan Trechsel zum 65 Geburstag (Zürich: Schulthess, 2003) pp. 357-358; A. Duff, 'Pre-trial detention and the presumption of innocence', in A. Ashworth, L. Zedner, P. Tomlin, eds., Prevention and the limits of criminal law (Oxford: Oxford University Press, 2013) pp. 128-131.

7 European Commission, Strengthening Mutual Trust in the European Judicial Area - A Green Paper on the Application of EU Criminal Justice Legislation in the Field of Detention, сом [2011] 327; Fair Trials, A Measure of Last Resort?, op. cit., p. 2. 
jurisprudence. ${ }^{8}$ This approach implies that these standards on pre-trial detention would merely require better enforcement: e.g. a periodic review of the grounds for detention. ${ }^{9}$ The nature of those grounds, and their underlying purposes, are rarely mentioned, let alone criticised. On the contrary, the compliance with ECHR standards is generally regarded as conducive to a moderate use of pre-trial detention.

In this paper we take issue with this approach. We critically analyse ECHR standards by focusing on what we refer to as their 'teleology', namely the set of purposes devised by the Court in its jurisprudence. Our hypothesis is that ECHR standards are far from being the solution to the excessive use of pre-trial detention registered in many EU Member States. By contrast, they represent the crux of the problem as they allow for (and in some cases incentivize) a greater resort to custodial measures. At the same time, these fail to provide guidance to national authorities for using alternative measures. To test our hypothesis, we draw on the analysis of ECtHR's jurisprudence. In parallel, in order to assess the impact of ECHR standards on national law we have built on recent comparative reports to extrapolate a few significant case studies. ${ }^{10}$ Following the Court's conceptualisation of the purposes of pre-trial detention, we concentrate on the ability of these standards to minimize the impact on the right to liberty and presumption of innocence.

\section{Understanding the Court's Teleology: ECHR Legal Standards on Pre-Trial Detention}

Pre-trial detention is a serious measure with negative consequences for the individual and her rights. This begs the question as to whether detention before (or pending) trial could be applied in a legitimate manner. ${ }^{11}$ National law depicts diversity in legitimising pre-trial detention. In some systems (e.g. Germany), arrest and continued detention are merged in a single measure, while in others (England and Wales, the Netherlands) they are formally categorised

8 CJEU C-294/16 PPU, JZ, 28 July 2016 points 51-52; C-310/18 PPU, Milev, points 6o-67.

9 E. Sellier, A. Weyembergh, Criminal procedural laws across the European Union - A comparative analysis of selected main differences and the impact they have over the development of EU legislation, (Brussels: Parliament, 2018) p. 102.

$10 \quad$ Supra note 1.

11 A. Ashworth, L. Zedner, Preventive Justice, (Oxford: Oxford University Press, 2014), p. 65; A. Duff, loc. cit., p. 119. 
as different measures. ${ }^{12}$ Time limits vary with some countries recognising maximum limits (e.g. Italy 6 years, and Spain 4 years), and others do not provide for maximum limits and, at least in practice, pre-trial detention can be renewed for undetermined periods (e.g. Netherlands, Germany, Hungary). ${ }^{13}$ Diversity exists also in review procedures. In Ireland detention orders are reviewed every 8 days, in Romania every 6o days, while in France review takes place every year. ${ }^{14}$ Legal diversity is often coupled with linguistic variety. ${ }^{15}$ 'Remand in custody' is more frequently used than 'pre-trial detention', especially in Englishspeaking systems. ${ }^{16}$ In other jurisdictions (Belgium) the term 'preventive detention' is popular, thereby alluding explicitly to some of its purposes.

The Convention and the Strasbourg jurisprudence operate as an overarching system of legal standards, which transcend national diversity. Hence, it developed autonomous legal concepts that, while not corresponding entirely to national definitions, are functional to the application of the Convention in the domestic setting. ${ }^{17}$ More specifically, the ECtHR has devised a tripartite structure which depicts the typical climaxing of pre-trial detention: arrest, police custody and continued detention. Each stage corresponds to distinct necessities of the criminal process: the initial apprehension of the suspect is meant to be short-termed and must be effective for different situations (e.g. caught redhanded, or after investigation); a period where the police may retain the suspect to build upon or verify initial suspicion; and, finally, a lengthier period of detention, necessary in a smaller amount of cases, where specific risks are identified that prompt the competent authority to refrain from releasing the suspect.

12 In Germany, there is one single measure, the arrest (Untersuchungshaft), for which judicial warrant is required (s. $112 \mathrm{StPO}$ ); it lasts 48 hours after which point it could be repealed or extended and in the latter case therefore transform into detention on remand. Dutch law prescribes a police custody of maximum 3 days and 15 hours (which could be extended, art. $57-58 \mathrm{~Sv}$ ) which is followed by a first stage of pre-trial detention, Bewaring, (art. $63 \mathrm{~Sv}$ ) lasting 14 days and ordered by the investigating judge and a second stage, Gevangenhouding, where detention can be order by a panel of three judges (art. $65 \mathrm{~Sv}$ ).

13 E. Sellier, A. Weyembergh, op. cit., p. 89 .

14 E. Sellier, A. Weyembergh, op. cit., pp. 91-92.

15 C. Morgenstern, 'Remand Detention in Europe: Comparative and Pan-European Aspects as Elements of a Wider European Penology, in T. Daems, D. van Zyl Smit, S. Snacken (eds.) European Penology? (London: Hart, 2013) pp. 193-216.

16 C. Morgenstern, 'Pre-trial/remand detention in Europe: facts and figures and the need for common minimum standards', 9 ERA Forum (2009), 527-542.

17 G. Letsas, 'The Truth in Autonomous Concepts: How To Interpret the ECHR', 15 European Journal International Law (2004), 279-305. 


\section{1 \\ The Court's Tripartite Structure and the Climax of Protection}

In order to understand how the ECtHR conceptualises pre-trial detention, one needs to consider the broader context of detention in its different stages. The ECtHR has grown increasingly stricter with the lawful standards for detention, in an effort to tackle its increasing abuse at national level, as violations of Article 5 ECHR represent the second most frequent violation of the Convention. ${ }^{18}$ Provisions of Article 5 par. 1 (c), 2, 3 and 4 ECHR lay down requirements of both substantive and procedural nature. ${ }^{19}$ Suspects can be arrested on 'reasonable suspicion' and remain under police custody no more than 4 days, even in cases of terrorism. ${ }^{20}$ After this initial period, they should appear promptly before a judge who reviews the lawfulness of detention ('first appearance'); this latter review is automatic. ${ }^{21}$ Besides being justified by a reasonable suspicion, detention at this early stage needs to be lawful, i.e. based on clearly defined legislation. ${ }^{22}$ Yet for pre-trial detention additional requirements exist as explained below.

Thus, the tripartite structure has normative value. It depicts the escalating strictness of legal standards. Especially, the first appearance signalises a shifting of gears as the conditions for deprivation thereinafter intensify. Given that authorities may detain suspects until that point without many restrictions, such period remains strictly short. Legal standards are climaxing as one moves along this linear structure. Legal requirements for continued detention are harder to comply with and become even stricter throughout the review procedure. Specific guarantees are set out under Article 5 par. 3, which apply only to pre-trial detention after a first appearance: they recognise the right of suspects, arrested or detained, to be brought to trial within a reasonable time. At the same time, this provision stipulates the person's right to be released pending trial.

The requirement of 'reasonable time' needs to be assessed in light of the circumstances of the case, therefore allowing for a certain degree of flexibility. Whereas the 'time factor' is key in the early stages of arrest and police custody, its relevance decreases once a judicial authority has stepped in to uphold the

18 European Court of Human Rights, Overview - Statistics 1959 to 2018, p. 6 https://www.echr .coe.int/Documents/Overview_19592018_ENG.pdf. W. Schabas, The European Convention on Human Rights: A Commentary (Oxford: Oxford University Press, 2015) pp. 227-250. ECtHR.

21 ECtHR, 3 October 2006, McKay v United Kingdom, appl. no. 543/o3, para. 34. 
lawfulness of detention. ${ }^{23}$ Indeed the Court has refrained from recognising a maximum period for pre-trial detention, unlike many national systems. ${ }^{24} \mathrm{But}$ this lenient attitude towards time is counterbalanced by a more rigid approach when it comes to the grounds that justify pre-trial detention. While during the initial stages of detention (arrest or police detention before first appearance) national authorities may satisfy themselves with a 'reasonable suspicion', a stronger justification is needed after first appearance. This is where the concern for the purposes of pre-trial detention comes to the fore.

\section{2 \\ A Focus on Purposes: ECtHR's Strategy for the Legitimacy of Pre-Trial Detention}

The Court has expanded on the set of procedural guarantees of Article 5 par. 3 (rights to judicial review, trial within reasonable time and release pending trial) by adding a further safeguard. One or more grounds of 'public interest' have to be present to justify continued detention and these should be 'relevant and sufficient'. 25 While reasonable suspicion constitutes a conditio sine qua non for the validity of continued detention, it does not suffice to justify it. ${ }^{26}$ In Buzadji, the Court has even gone further, by rejecting the lawfulness of pre-trial detention in the absence of grounds of 'public interest'. Until Buzadji, the ECtHR allowed continued detention merely on grounds of reasonable suspicion for an undefined initial period. So, even after first appearance, detention could continue only on the basis of reasonable suspicion and it was only after 'a certain lapse of time' that public interest grounds were required. But in Buzadji, the Court overruled its previous jurisprudence and abolished pre-trial detention solely on reasonable suspicion. Since this judgment, any detention ordered after first appearance must be based also on public policy grounds.

Insisting on the purposes of detention is a well-thought strategy. It aims at differentiating pre-trial detention (allowed under Article 5 par. 1c) from detention after conviction (allowed under Article 5 par. 1a). Ideally, continued

23 The second limb of Article 5 par. 3 requires that the length of pre-trial detention is 'reasonable'; however, it is 'admitted on all sides that it is not feasible to translate this concept into a fixed number of days, weeks, months or years, or into various periods depending on the seriousness of the offence', see ECtHR, 10 January 1969 Strogmöller v Austria, appl. no. $1602 / 62$, para. 4 .

24 ECtHR, 5 July 2016, Buzadji v. Moldova, para. 9o. Here, the Court has rejected the stance taken in the case $W . v$ Switzerland, appl. no. 14379/88, para. 30 that Article 5 par. 3 implies a maximum length of pre-trial detention. This line of argument has been endorsed by S. Trechsel, op. cit., p. 523. Contra D. J. Harris, H. O'Boyle, E.P. Bates, C.M. Buckley, Law of the European Convention on Human Rights (Oxford: Oxford University Press, 2014), p. 145.

25 Buzadji par. 102.

26 ECtHR 27 August 1992 Tomasiv France, appl. no. 1285o/87, par. 84. 
detention does not share the same purposes of sentencing (e.g. rehabilitation, retribution). On the contrary, it remains a temporary interference with liberty, which must be grounded on interests that are rigorously differentiated from those of a custodial sentence. ${ }^{27}$ However, similar to custodial punishment, pretrial detention is inherently utilitarian in that it must serve an identifiable benefit - i.e. protecting the investigation, the victim or the society at large.

The 'strategy' of underpinning pre-trial detention with a well-identified purpose is instrumental to the protection of several Convention's rights: not only the right to liberty, but also the presumption of innocence. The assumption seems to be that when a 'genuine public interest' exists, this should be weighed against these rights. Significantly, the Court does not believe that these interests or grounds could be exhaustively enumerated. ${ }^{28}$ On the contrary, a number of motives have been considered 'relevant and sufficient' for detention. Despite having in common their risk-oriented nature, these grounds show how a set of diverse (and somewhat vague) interests which can be invoked to keep someone in custody.

An analysis of the Court's jurisprudence reveals that the following grounds are most recurrent: the risks of absconding, tampering with evidence, reoffending and disturbing public order. ${ }^{29} \mathrm{~A}$ fifth ground has been put forward by some earlier judgements, i.e. the protection of the defendant, but was not consistently developed in later case law. ${ }^{30}$ Risk of absconding refers to the risk that the suspect flees justice; risk of reoffending is relevant when the suspect can reasonably be expected to reoffend; risk of tampering with the investigation includes situations where there are fears of collusion, intimidation of witnesses or destruction of evidence; ${ }^{31}$ finally, the disturbance of public order refers to situations when the suspect's release pending trial would lead to public disturbance. ${ }^{32}$ Both risks of absconding and tampering with evidence refer to interests of the proceedings, namely the danger that the suspect might obstruct the course of justice. By contrast, the other two grounds relate to interests external to the proceedings and pertinent to the State's responsibility or duty to protect (the victims, the community, and even the offender).

\footnotetext{
27 ECtHR, 3 October 2006, McKay v United Kingdom, appl. no. 543/o3.

28 B. Rainey, E. Wicks, C. Ovey, Jacobs, White and Ovey. The European Convention on Human Rights, (Oxford: Oxford University Press, 2014) p. 226.

29 ECtHR, 24 July 2003, Smirnova v Russia, par. 59; Czarnecki, par. 43.

$30 \quad$ ECtHR, 23 September 1998, I.A. v France, appl. no. 28213/95, par. 108; ECtHR, 8 November 2007, Lilievre v Belgium, appl. no. 11287/03 par. 104.

31 S. Trechsel, op. cit., p. $5^{26 .}$

32 ECtHR, 26 June 1991 Letellier v. France, par. 51.
} 
The question arises as to whether these various justifications can outweigh the right to liberty and the presumption of innocence. This is particularly delicate since the concept of 'public interest' remains rather opaque, as we will argue more in depth. ${ }^{33}$ The Court appears aware of it and has introduced a set of procedural limitations to restrict national courts' discretion. A number of material constraints restrict judicial decision-making when assessing the 'risks' that justify pre-trial detention. The risk of absconding, for example, cannot be inferred 'solely on the basis of the sentence incurred'; rather, it must be assessed 'with reference to relevant factors', ${ }^{34}$ which may confirm or rule out the existence of a risk of flight. ${ }^{35}$ Similar rules are restated in relation to the risk of tampering with evidence. ${ }^{36}$

These justifications can be valid at an early stage of a proceeding but tend to fade with the passing of time. Therefore, national authorities will have to provide specific reasons showing why a suspect must remain longer incarcerated. ${ }^{37}$ Similarly, the risk of reoffending cannot be gauged only on the basis of their antecedents. Yet, the presence of previous convictions may give grounds for pre-trial detention if the risk of re-offending is plausible and the use of detention appears appropriate in light of the circumstances of the case and, in particular, the past history and the personality of the person concerned..$^{38}$ Interestingly, this ground may also be used when charges are particularly serious and the corroborating factors listed above (e.g. the personality of the offender) confirm the assessment of risk. ${ }^{39}$

The said restrictions are aligned with the duty to avoid 'abstract, generalised and stereotypical' reasoning while deciding between detention and release. ${ }^{40}$ The ECtHR attaches importance to the context: to substantiate the grounds indicated above, national authorities must look into the specifics of each case ${ }^{41}$ an abstract reasoning could lead to a broad application. Furthermore,

34 ECtHR, 8 February 2005, Panchenko v. Russia, appl. no. 45100/98 par. 106.

35 Smirnova par. 6o: 'the character of the person involved, his morals, his assets, his links with the state in which is being prosecuted'.

36 This risk cannot cannot be based only on the likelihood of a severe penalty, but must be linked to specific facts, see ECtHR, 5 July 2016, Merabishvili v. Georgia, appl. no. 23755/07, par. 224 and 228; see, however, ECtHR, 13 April 2017 Podeschi v. San Marino, par. 149.

The assumption being that the 'risk of flight necessarily decreases with the passage of time spent in detention' ECtHR, 27 June 1968, Neumeister v. Austria, appl. no. 1936/63.

38 ECtHR, 13 January 2009, Giorgi Nikolaishvili v. Georgia, appl. no. 37048/04, par. 73 and 76; ECtHR, 26 March 2013, Luković v. Serbia, appl. no. 43808/o7, par. $5^{2}$.

39 ECtHR, 12 December 1991, Clooth v Belgium, appl. no. 12718/87, par. 40.

40 ECtHR, 8 June 1995, Yagci and Sargin v Turkey, App 16419/90, 16426/90, para $5^{2}$.

41 Buzadji, par. 102. 
national courts are expected to provide a sophisticated decision-making process showing consistency. This requires them to assess also how previous decisions were made: e.g. the grounds that were previously deemed irrelevant cannot suddenly become relevant and sufficient without any factual or personal change. ${ }^{42}$

The obligation to avoid abstract and stereotypical reasoning goes hand in hand with the duty to consider alternatives to pre-trial detention and use this only as a measure of last resort. This obligation poses a further restriction on judicial decision-making: it forces the competent authority to convincingly demonstrate that a period of detention, no matter how short, is justified in relation to the risks posed by the suspect. In order to do so, the competent authority needs to rule out the possibility of 'alternative non-custodial pre-trial measures.43 More specifically, in Caballero, the Court has stated that if a system were designed 'to automatically refuse bail' - i.e. without an assessment into the facts of the case - it would be incompatible with the Convention. ${ }^{44}$ Indeed, the last sentence of Article 5 para 3 recognises that release could be made conditional on additional guarantees. The duty of considering alternatives (and the corresponding right of a suspect to be considered for bail) remains rather fuzzy, as it will be explained.

\section{$3 \quad$ Has the ECtHR got it Wrong? A Critical View on the Court's Teleology}

As explained above, the Court has developed its legal standards and guarantees in order to minimize the impact of deprivation of liberty on an individual's rights. According to the Court's own definition, 'detention can be justified in a given case only if there are actual indications of a genuine requirement of public interest which, notwithstanding the presumption of innocence, outweighs the rule of respect for individual liberty laid down in Article 5 of the Convention', ${ }^{45}$ In other words, a lawfully ordered pre-trial detention is always the outcome of a delicate weighing exercise between opposing interests involving the individual and a State's authorities. The question however arises as to whether the ECtHR's strategy is normatively sound and appropriate to ensure an adequate balance with those principles. In this section, we delve into

\footnotetext{
42 Buzadji, par. 122.

43 Nikolaishvili v. Georgia, par. 79. For a slightly different principle in the previous case law, see ECtHR, June 27, 1968 Wemhoff v. Germany, appl. no. 2122/64, Series A No. 7.

44 ECtHR, 8 February 2000, Caballero v. the United Kingdom, appl. no. 32819/96, par. 21.

45 Buzadji, par. 90.
} 
this question. We begin by pointing out a number of shortcomings and contradictions in the Strasbourg's jurisprudence. We then move on to consider national law and practice in order to assess the impact of ECHR standards.

\subsection{Shortcomings and Contradictions in ECHR Standards on Pre-Trial Detention}

As indicated above, recent empirical findings in Europe show an overreliance on detention against suspects and defendants, going beyond the strict requirement of ultima ratio. ${ }^{46}$ While this is partly down to national legislation and domestic judicial cultures, we believe that ECHR standards are also to blame. These standards are inherently insufficient, as they do not offer adequate protection against overuse. More specifically, whereas the ECHR has focused on the grounds of detention and other detailed procedural rules, other material aspects are inadequately addressed. The Court's jurisprudence does not tie pre-trial detention to the level of punishment in abstracto - as an expression of proportionality. ${ }^{47}$ Yet, some national jurisdictions in the EU link pre-trial detention to the possibility of a custodial sentence if found guilty. Other legal systems provide for more severe thresholds and allow detention only when the offence is punishable by a minimum term of imprisonment, e.g. in Italy ${ }^{48}$ and Portugal ${ }^{49} 5$ years; in the Netherlands ${ }^{50} 4$ years, in France 3 years. ${ }^{51}$

This lacuna in the Court's case law should be understood as a form of deference vis-à-vis the State's margin of appreciation - in keeping with the principle of subsidiarity underpinning the Convention system. It is nevertheless worrisome that, in some jurisdictions, detention can be ordered regardless of the penalty faced by the suspect at the end of trial (even when the offence carries a non-custodial punishment). Although this state of things is clearly at odds with the principle of proportionality, there is no explicit reference to this requirement in the Court's case law. More attention to proportionality is therefore in order.

46 In some jurisdictions key actors involved in remand proceedings consider pre-trial detention as a default option. See, in particular, the results of the vignette experiment conducted in the context of DETOUR, op. cit., p. 77 .

47 See Z. Bathyar, A. Kalmthout, M.M. Knapen, P. Lambertina, loc. cit., p. 69.

48 B. Bertolini, S. Carnevale, M. Lombardi, A. Martufi, 'Italy', in A. Bernardi (ed.), A. Martufi (coord.), Prison overcrowding and alternatives to detention. European Sources and national legal systems (Napoli: Jovene, 2016), p. 243.

49 Z. Bathyar, A. Kalmthout, M.M. Knapen, P. Lambertina, loc. cit., p. 69.

5o J. Crijns, B. J. G. Leeuw, H. T. Wermink, Pre-trial detention in the Netherlands. Legal principles versus practical reality, (Den Haag: Eleven, 2016), p. 17.

$5^{1}$ See J. Alix, G. Giudicelli-Delage, C. Mauro, R. Parizot, J. Tricot, 'France' in A. Bernardi (ed.), A. Martufi (coord.), loc. cit., p. 196. 
This is all the more important since practice at national level reveals a possible distorted application of proportionality: the seriousness of the offence - as depicted in the penalty - may serve as the sole ground for detention, instead of being only an in abstracto threshold of whether pre-trial detention is an available measure. At the same time, in some legal systems e.g. the Netherlands, courts must anticipate the possible length of imprisonment in the case of a guilt verdict, to prevent that the defendant will sit in pre-trial detention longer than the given penalty. Domestic courts must therefore employ a sophisticated legal reasoning: the seriousness of the offence and the possibility and level of custodial sentence are factors to be taken into account, but in more than one ways during the very same legal decision. As we will explain below, more attention to proportionality may also be relevant to guide the choice of alternatives to pre-trial detention. After all, a proportionality test - although not prescribed by the Court - is implicit in the logic of using pre-trial detention as a measure of last resort.

Furthermore, the grounds for pre-trial detention chosen by the ECtHR sit uneasily with the presumption of innocence. As explained above, the Court has devised four 'public interest' grounds, which correspond to acceptable policy goals to restrict liberty. ${ }^{2}$ However, at a closer look, the risk of reoffending is problematic. Although this ground is now incorporated in the legislation of all EU member states, ${ }^{53}$ it has been met with resistance in some jurisdictions (e.g. Ireland $)^{54}$ and has never ceased to spark criticism among scholars for its lack of compliance with the presumption of innocence. ${ }^{55}$ These concerns are tangible if one looks at the criteria devised by the Court to assess the risk of reoffending, as they give way to stereotypical assumptions regarding the assessment of prior record as indication of risk. Worryingly, the seriousness of the offence may be regarded as an element to predict the likelihood of re-offending. Building on the gravity of the offence to predict the risk of reoffending logically implies that the suspect has committed such offence. ${ }^{56}$ All

$5^{2}$ M.S. Groenhuijsen, 'De nabije toekomst van de voorlopige hechtenis, in het bijzonder in het licht van de onschuldpreasumptie', in J. de Hullu W.E.C.A. Valkenburg (eds.), Door Straatsburg geïnspireerde grondnormen voor het Nederlandse strafproces (Deventer: Tjeenk Willink, 2000), pp. 95.

53 DETOUR, op. cit., p. 13.

54 M. Mellett 'Pre-trial detention in Ireland' P. H. van Kempen (ed.) Pre-trial Detention. Human Rights, criminal procedural law and penitentiary law, comparative law (Antwerpen: Intersentia, 2012), pp. 461-494.

55 See, inter alia, P. A. Albrecht, , op. cit., pp. 357-358; A. Duff, , loc. cit.

56 T. Weigend, 'Assuming the defendant is not guilty: The presumption of innocence in the German System of Criminal Justice', 8 Criminal Law, Philosophy (2014), p. 298: the very fact 
in all, the risk of re-offending seems to encourage a detention that is purely preventive.

Additionally, some grounds are too vaguely defined by the Court, thereby bestowing excessive discretion on national authorities. One such example is the ground of disturbing the public order. This justification can only be used in exceptional cases, when there is proof of an actual risk of public disturbance. ${ }^{57}$ These mild restrictions did not prevent some national authorities to resort extensively to the notion of 'public order' (e.g. the Netherlands). ${ }^{58}$ Perhaps due to the vagueness of its own criteria in this area, the Court has 'saved' long periods of detention (e.g. three years), even when justified only on this ground, e.g. in Hendricks and in Kanzi. ${ }^{59}$ This is surprising as usually the likelihood of public disorder decreases with the passage of time. It should be noted that some scholars interpret this ground differently. For Ashworth the protection of public disturbance aims at the protection of the suspects of serious offences. ${ }^{60}$

On a different note, one may even challenge the ability of the presumption of innocence to serve as a benchmark for critically evaluating the practice of pre-trial detention at national level. A review of the current literature on the argument elicits various interpretations of the presumption of innocence, which emerges as a rather abstract and contested concept. ${ }^{61}$ Understanding what it entails is so elusive that scholarship has put more effort into actively explain what the presumption of innocence is not about. ${ }^{62}$ The choice of what grounds actually comply with the presumption of innocence is also disputed. Duff argues that only the risks of absconding and obstruction of justice would be in line with the presumption, ${ }^{63}$ while other scholars have shown support for a less strict interpretation of this principle. Looking at the indeterminacy of

of assessing whether the suspect might 're-offend' builds upon the assumption that the suspect has committed the offence.

57 Letellier, par. 51.

$5^{8} \quad$ Fair Trials, op. cit., p. 2.

59 ECtHR, 5 July 2007, Hendricks $v$ The Netherlands appl. no. 28831/04 (decision as to the admissibility); ECtHR 5 July 2007, Kanziv The Netherlands appl. no. 43701/04 (decision as to the admissibility).

6o A. Ashworth, M. Redmayne, The Criminal Process (Oxford: Oxford University Press, 2010) p. 213 .

61 See for a collection of debating views, F. de Jong, L. van Lent, 'The Presumption of Innocence as a Counterfactual Principle', Utrecht Law Review (2016), p. 34; A. Ashworth, 'Four threats to the presumption of innocence', 10 The International Journal of Evidence and Proof (2006) p. 241-279.

62 T. Weigend, loc. cit., p. 288, who further explains how to separate the presumption of innocence from other procedural safeguards e.g. fair trial.

63 A. Duff., loc. cit., p. 122. 
the presumption of innocence and the plurality of views, ${ }^{64}$ one might seriously raise the question whether it has any 'operational value' in limiting the use custodial measures. ${ }^{65}$ Since the ECtHR standards are supposedly designed to fulfil or express the presumption of innocence, it would be prudent to first investigate and come to an agreement of what this principle means and its role in limiting pre-trial detention. Thus, fixing pre-trial detention requires a reevaluation of theoretical foundations, and the presumption of innocence should be first in line.

\subsection{A Duty to Consider Alternatives? Vagueness of ECHR Standards on Bail}

As mentioned above, ECHR standards generate the obligation to seek the use of alternative measures before ordering detention (and to consider them instead of detention in every following review). But what exactly does this obligation entail? And here is where the ECHR standards fail to provide guidance to a significant degree. This lack of guidance is partly due to the ambiguity of the term 'alternative'. In a European context there is no consensus around what this concept entails. A great deal of confusion derives from the use of the term 'bail', which in some comparative studies is used only to denote financial guarantees deposited or pledged to secure the suspect's participation at trial. ${ }^{66} \mathrm{By}$ contrast, especially in the English-speaking countries, this concept has been commonly understood in a much broader sense: as synonym to 'a status in which the suspect is obliged to turn up before court or before the police (often with conditions attached to secure this aim) ${ }^{\prime}{ }^{67}$ This wider understanding coincides with the notion of 'alternatives' commonly used in the supranational and European jargon. ${ }^{68}$

64 See the very interesting juxtaposition of the continental and American dogmas in J.Q. Witman, 'Presumption of Innocence or Presumption of Mercy?: Weighing Two Westerns Models of Justice', 94 Texas Law Review (2016) pp. 933-993.

65 L. Stevens, 'Pre-Trial Detention: The Presumption of Innocence and Article 5 of the European Convention on Human Rights Cannot and Does Not Limit its Increasing Use', $17 \mathrm{Eu}$ ropean Journal of Crime, Criminal Law and Criminal Justice (2009) 165-180, p. 171; F. de Jong, L. van Lent, loc. cit., p. 41.

66 This is the way the term 'bail' is used in the such reports as Z. Bathyar, A. Kalmthout, M.M. Knapen, P. Lambertina, C. Morgenstern et al. loc. cit., p. 92, and P. H. van Kempen op. cit., p. 45 .

67 C. Morgenstern, 'Alternatives to Pre-trial Detention' in G. Bruinsma, D. Weisburd (eds), Encyclopedia of Criminology and Criminal Justice (New York: Springer 2014), p. 70.

68 For an example of a widely encompassing use of the term 'alternatives', see Council of Europe's Recommendation $\operatorname{Rec}(2006) 13$ on the 'rules on the use of remand in custody' (see in particular Rule 2) and, at the EU level, the Commission's Green Paper on detention, p. 8. 
While the ECtHR has made a consistent effort to devise an autonomous concept of pre-trial detention (see above), it failed to do the same with its alternatives. This is all the more striking given that, as we explained earlier, the Court's jurisprudence has incorporated the duty for national authorities to seek for alternatives. Yet, the Court's reluctance to engage with definitions may be understood in light of the extraordinary variety of domestic legal arrangements in this area. There, two key models can be distinguished: the 'bail model' (e.g. England and Wales, France and Poland) allows the competent authority to choose between unrestricted liberty, a release with conditions (conditional bail) and remand on custody; the 'suspension model', (e.g. Belgium, Spain, the Netherlands) requires the fulfilment of grounds for detention as a precondition and only if this can be done may the judge choose a less restrictive measure. ${ }^{69}$

A first attempt to understand the meaning of 'alternative' in the Convention starts from the analysis of Article 5 ECHR. The last sentence of paragraph 3 reads as follows: 'Release may be conditioned by guarantees to appear for trial'. A strict interpretation of this poorly drafted provision suggests that the only 'alternative' accepted under the Convention is a form of financial bail. ${ }^{70}$ Indeed, a number of cases seem to refer to the notion of bail exclusively in terms of financial security. ${ }^{71}$ However, such a narrow interpretation is problematic as it narrows down the palette of available alternatives, thereby limiting the scope of the legal requirement to consider alternatives. The wording of Article 5 par. 3 poses significant restrictions even if we were to interpret the notion of bail in a broader fashion. This text only refers to the risk of absconding as the main purpose that would justify the use of bail. ${ }^{72}$ But how about the other purposes of pre-trial detention? Can there be alternatives for the other risks? This remains unclear.

These problems are amplified by the fact that there must be a functional link between the purposes of pre-trial detention and alternatives. Ideally, the competent authority must choose, from a palette of different measures, the most adequate to achieve the goals that would otherwise be served by pretrial detention. Yet, alternatives such as financial bail are not always adequate

69 M. Boone, M. Herzog-Evans, 'Decision-making and offender supervision' in K. Beyens, F. McNeill eds., Offender supervision in Europe (Basingstoke: Palgrave McMillan, 2015), p. 59.

70 R. Vogler, S. Fouladvand, 'Standards for making factual determinations in arrest and pretrial detention: a comparative analysis of law and practice', in J. E. Ross, S. C. Thaman, (eds.) Comparative criminal procedure. Research handbooks in comparative law. (Cheltenham: Edward Elgar, 2016), pp. 191-216.

71 ECtHR, 22 May 2018 Gafà v Malta, appl. no. 54335/14, par. 70.

72 ECtHR, 12 May 2012, Idalov v. Russia, appl. no. 5826/o3. 
to replace pre-trial detention: e.g. to prevent re-offending. As Trechsel put it 'for practical reasons bail is an option almost exclusively in cases where the detention is justified by the danger of the suspect absconding. ${ }^{73}$ This view seems confirmed by some Court's judgements ('the fear that the accused will flee and thus avoid appearing trial'), while in others the ECtHR has more ambiguously mentioned a general obligation to seek alternative non-custodial pre-trial measures, irrespective of the purpose. ${ }^{74}$

Even more controversially, in a parallel line of case law, the Court has addressed the discussion of other alternatives (e.g. the travel ban) under Article 2 of Protocol n. 4 on the right to the freedom to movement. Apparently, the Convention makes a normative distinction between more and less restrictive measures based on their impact on the right to liberty. However, the underlying reasons for this conceptual divide are from clear. For instance, house arrest typically falls under Article 5 ECHR, as the degree and intensity of its restrictions may be similar to those of detention. ${ }^{75}$ The same goes for some - but not all - forms of compulsory residence as the Court made clear in Guzzardi. ${ }^{76}$ But a night curfew coupled with other obligations (e.g. report to the police station) falls under the Protocol. ${ }^{77}$ This division between measures falling under Article 5 and those covered by the Protocol has normative implications in that different standards of protection apply. While measures of Article 5 follow the strict requirements applying to pre-trial detention, alternatives under the Protocol are subject to more lenient safeguards and leave greater room to State's margin of appreciation..$^{78}$

A further dilemma related to this divide is whether the measures falling under Article 5 ECHR can be actually regarded as alternatives to detention. This question arises as, in those cases, the level of restriction imposed on the suspect is equivalent to one of detention. In other words: is the duty to consider alternatives effectively fulfilled when the national authorities, in a bid to avoid the remand in custody, choose a measure substantially akin to detention? The relevance of this problem can hardly be underestimated. In fact, legislators

73 S. Trechsel, op. cit., p. 532.

74 Nikolaishvili.,par. 73. In other cases, the Court has only referred to the possibility of 'release on bail', this must be understood as a reference to the deposit of a financial security and therefore relevant only in cases where risk of absconding exists, ECtHR, Ambruszkiewicz v Poland, appl. no. $38797 / 03$.

75 Buzadji op. cit..

76 ECtHR, 6 November 1980, Guzzardi v. Italy, §§ 92-93.

77 ECtHR, 22 February 1994, Raimondo v Italy, appl. no. 12954/87.

78 ECtHR, 6 April 200o, Labita v Italy, app. no. 26772/95; ECtHR 23 February 2017, De Tommaso $v$ Italy appl. no. 43395/o9, par. 80. 
and policy-makers at the national level seem increasingly eager to enhance the credibility of alternative measures by attaching further restrictions to measures enforced in the community (e.g. via a more frequent use of electronic monitoring) and increase controls to enforce compliance with their obligations. ${ }^{79}$ In light of the Court's approach on one may doubt that a massive use of such intrusive measures would always satisfy the obligation to go for the least restrictive measure.

The question briefly touched upon above concerns the ambiguity of the obligation devised by the Court as regards the use of the alternatives. Is this duty solely a way to encourage a more lenient treatment to bring the suspect to trial? Or is it part of a broader obligation to positively choose in any case the least restrictive measures? This latter solution would imply an assessment of proportionality (or, better said, the 'strict necessity') of remand measures in relation to both their purposes and effects. Yet, the Court has systematically avoided to explicitly require a proportionality test. ${ }^{80}$ In this respect, one would expect more tangible criteria to guide national authorities in the choice of the alternatives: e.g. connecting the use of more lenient measures with the threshold of the threatened punishment (thereby excluding the use of custody for petty offences) or binding the judge to order an alternative when there is no risk of harm for the victims. In this respect, the Court has not identified factual situations that indicate when alternatives should be preferred and generalised as a default option.

\subsection{Looking Beyond the ECHR: Strasbourg's Standards in National Law}

The inconsistencies and vagueness of ECHR standards are confirmed if one looks at national law and practice. A complete overview of the state of affairs at domestic level falls beyond the scope of this paper. Rather we build on some 'highlights' (taken from recent comparative studies) in order to illustrate how the Court's authority on 'purposes' has so far been unable to prevent an overuse of pre-trial detention. More specifically, one has to look at the way in which

79 M. Boone, N. Maguire, 'Aims, concepts, methodologies and figures' in M. Boone, N. Maguire eds. The Enforcement of Offender Supervision in Europe. Understanding breach processes (Abingdon-on-Thames: Routledge 2017), pp. 6-18.

8o While the requirement of 'scrict necessity' is to some extent implicit in the logic of ultima ratio, the Court has been reluctant to incorporate this in its interpretation of Article 5 par. $3 \mathrm{ECHR}$. As a general rule, the exceptions to the right to liberty are not subject to the principle of proportionality and the Court has often confined its interpretation of Article 5 to the criteria of lawfulness and arbitrariness; see J. Christoffersen, Fair Balance: A Study of Proportionality, Subsidiarity and Primarity in the European Convention on Human Rights, (Leiden: Nijhoff, 2009), p. 117. 
national standards, while formally in compliance with the Court's teleology, endorse (or indirectly allow) practices that put both the right to liberty and the presumption of innocence under strain. This may appear surprising as domestic grounds for pre-trial detention (and the purposes thereof) are for the most part aligned with the taxonomy devised by the ECtHR. Yet, ECHR standards fail to provide clear indications about the proportionality in the use of pre-trial detention and allow the use of custody on preventive grounds.

As for the issue of proportionality, some jurisdictions allow for pre-trial detention even when the sentence faced is very low or when the person incurs a non-custodial penalty. ${ }^{81}$ Where thresholds are established, they usually identify a minimum level of the maximum penalty, i.e. the statutory penalty or sentence in abstract. But whereas judicial discretion exists, the actual sentence may be significantly lower. To avoid a disproportionate use of detention some jurisdictions (e.g. Italy, ${ }^{82}$ the Netherlands ${ }^{83}$ ) require the competent authorities to carry out a predictive assessment as to the length of final sentence: while this solution may be problematic for a number of reasons (e.g. it implies a judgement of guilt and risks influencing the subsequent court's verdict), it may at least discourage the use of detention in most trivial cases.

On the other hand, the legislation of most EU member states recognises the use of pre-trial detention on preventive grounds. We have already elaborated as to why this ground may appear problematic to reconcile with the presumption of innocence. In some cases, the use of pre-trial detention to prevent reoffending is confined to the most serious categories of offences (e.g. Germa$n^{84}$ and Spain ${ }^{85}$ ): though such restrictions could help reducing the influence of this ground in practice, they do have the negative side-effect of linking the need for prevention (risk of repetition) to the seriousness of charges. This may lead the judge to avoid an in-depth assessment of the risks posed by the suspect, paving the way for a stereotypical judgement based only on the charged offence. More generally, recent empirical findings provide an insight into the widespread reliance on preventive concerns among judges and prosecutors in Europe. With few exceptions (Ireland ${ }^{86}$ ), interviewed practitioners in most EU

81 H.J. Albrecht, Pre-Trial Detention in Germany: The Empirical Situation, H.J Albrecht and C. Guangzhong, eds. Coercive Measures in a Socio-legal Comparison of the People's Republic of China and Germany (Freiburg im Breisgau: Max Planc Institut, 2044), p. 117-136.

82 B. Bertolini, S. Carnevale, M. Lombardi, A. Martufi, 'Italy', loc. cit., p. 249.

83 J. Crijns, B. J. G. Leeuw, H. T. Wermink, op. cit., p. 17.

84 C. Morgenstern, Die Untersuchungshaft, op. cit., p. 459.; T. Weigend, ' loc. cit. , p. 298.

85 J. L. Diez-Ripollés, C. Guerra-Pérez, 'Pre-trial detention in Spain', 18 European Journal of Crime, Criminal Law and Criminal Justice (2010), 398-399.

86 D. Perry, M. Rogan, Detour. Towards Pre-trial as Ultima Ratio - First National Report on Germany, (Dublin: Trinity College Dublin, 2016), p. 9. 
countries list the prevention of re-offending as their greatest concern during the investigation. ${ }^{87}$

In our view, one of the causes for this is that pre-trial detention fulfils heterogeneous purposes, depicting a diversity that ECHR standards seemingly fail to address. As explained, preventive pre-trial detention is different from the 'classical' custody on remand: while the latter is ordered to safeguard the interests of a proceeding (risk of collusion and absconding), the former performs different functions that relate to broader interests of criminal policy. ${ }^{88}$ Accordingly, pre-trial detention when based on preventive grounds presents the typical problems of preventive justice: it challenges individual autonomy, ${ }^{89}$ it is notoriously shaky in its claim to predict and define risk, ${ }^{90}$ and, therefore, can lead to overuse and abuse. Indeed, recidivism is so hard to give grounds for an objective assessment that some commentators have provocatively observed that in national law 'the risk of re-offending is there when you want it to be.91

Despite the ECtHR's constraints, the arguments to substantiate this ground are usually stereotyped and boil down to the social and economic conditions of a suspect (e.g. substance dependency, financial problems) ${ }^{92}$ or to the seriousness of the offence. Furthermore, the mentioned empirical studies underline an inter-changeability of risks. In other words, national courts tend to choose the legal grounds that would better achieve the outcome that fits their view on the suspect, regardless of legal considerations. In Germany, for instance, interviews conducted with prosecutors show that, although the main motive to request incarceration is often the risk of re-offending, judges would formally link the choice of detention with the risk of absconding. As a matter of fact this ground offers a more legally viable option, as in Germany legal prerequisites for the risk of repetition are very strict.

Additionally, the practice at national level is conducive to the proliferation of 'hidden grounds' for detention. ${ }^{93}$ Significantly, most of these 'hidden grounds' coincide with factors or elements of proof that the Court has ruled out as being 'insufficient' or 'irrelevant' ${ }^{94}$ For one thing, national authorities

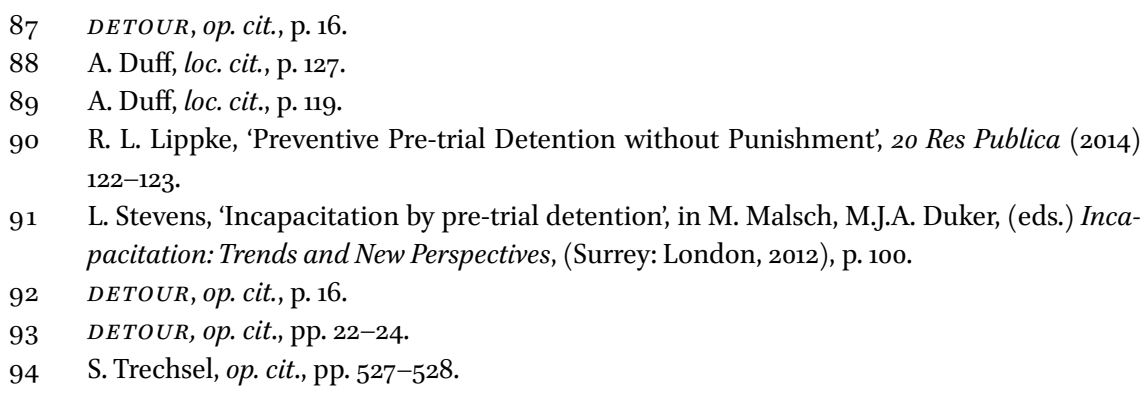


usually put forward unspecified needs or requirements of the investigation, which could be hampered if a suspect is not held in custody. Evidence suggests that these unspecified threats to the investigations could be particularly alarming in the case of foreign offenders and non-residents. ${ }^{95}$ Other hidden grounds include the attempt to give the suspect a 'taste of imprisonment', a form of 'shock inceraceration' with supposed deterrent effects. Paradoxically, this practice may appear particularly 'attractive' for prosecuting authorities where the risk exists that charges may not result in a custodial sentence. The latter scenario lays bare retributive elements in the practice of pre-trial detention.

In this last section we shall summarize our main points and furthermore ponder on how to proceed, especially for the purpose of initiatives at EU level since the latter emerges as a more dynamic field of standard-setting. In our contribution we have contested the appropriateness of ECHR standards to keep abusive and excessive detention at bay. To summarize, four main issues underpin our criticism of the ECHR's logic and the way this operates in national law. First, the ECHR standards may be insufficient and leave excessive discretion to national authorities. Second, some grounds are not aligned with the presumption of innocence, which remains an undetermined concept. Third, pre-trial detention in national law appears to fulfil heterogeneous purposes begging the question as to whether the ECHR standards fail as being 'one-size fits all'. Within those functions, one can detect even retributive elements, which further jeopardise the presumption of innocence and fairness of pre-trial detention. Finally, the ECtHR does not give clear guidance on how to fulfil the obligation to seek and prefer alternatives. Alternative themselves do not have coherent legal standards as they straddle across two different articles in the Convention, whereas tools to apply a proportionality test are missing.

One may wonder how these points can be incorporated into EU law. More specifically, EU law and the CJEU have picked up the tab on setting procedural standards for criminal proceedings. This development takes place within the context of an increasing approximation between the ECHR and the Charter of

95 Numerous studies have demonstrated that foreign prisoners tend to be overrepresented among pre-trial detainees. The high rate of foreigners is often explained as a consequence of their lack of fixed domicile or even the absence of a residence permit, as these factors are (formally or, more frequently, informally) regarded as indicators of risk of flight and/ or risk of reoffending; Z. Bathyar, A. Kalmthout, M.M. Knapen, P. Lambertina, 'op. cit., p. 69 . 
Fundamental Rights of the EU (see Article $5^{2}$ of the latter). Against this backdrop, pre-trial detention has increasingly become the 'hot potato' of European criminal justice, with advocates calling for the adoption of EU minimum rules and prospects of new initiatives by the European Commission in this area. ${ }^{96}$ However, while attempts to establish harmonised standards have so far stalled, ${ }^{97}$ the CJEU seems inclined to fall back on ECHR standards in dealing with pre-trial detention. ${ }^{98}$ These references have increased as a response to the 'constitutional' crisis sparked in the aftermath of Aranyosi. ${ }^{99}$

In spite of this, our findings in this article show that any attempt to harmonise pre-trial detention standards, either through a legislative instrument or via the CJEU's case law, runs a great risk of failure in the absence of a critical reception and improvement of ECHR standards. As explained, EU law initiatives tend to rely on ECHR standards without a substantial re-evaluation of their contents. One conclusion of this article is that if the EU were to improve the rational use of pre-trial detention, ECHR standards should not be considered adequate to ensure that pre-trial detention remains a measure of last resort. The difficulty to reduce the overuse of pre-trial detention is even greater when it comes to cross-border issues involving judicial cooperation. This becomes evident from the outright failure of the European Supervision Order (ESO), ${ }^{100}$ which is hardly ever used due to the lack of acceptable standards of pre-trial detention and alternatives. ${ }^{101} \mathrm{~A}$ solid starting point would be to appreciate the ECHR standards for what they truly are: minimum. ${ }^{102}$ Drawing on this premise, in our analysis we located certain areas where there is room for improvement.

96 C. Riehle, A. Clozel, '10 years after the roadmap: procedural rights in criminal proceedings in the EU today' Era Forum (2019), published online 2 October 2019, pp. 1-5.

97 Green Paper, op. cit.; T. Coventry, 'Pretrial detention: Assessing European Union Competence under Article 82(2) TFEU' 8 New Journal of European Criminal Law (2017) 43-63.

98 CJEU, 28 July 2016, C-294/16 PPU, JZ, point 51-52; C-310/18 PPU, Milev, points 6o-67; see also AG Wathelet Opinion in Milev, 7 August 2018.

99 CJEU 5 April 2016, Joined Cases C-404/15 and C-659/15 P PU, Aranyosi and Căldăraru.

100 EU Commission, Green Paper, op. cit. Also, pre-trial detention was excluded from the Directive on the Presumption of Innocence (mentioned only in the preamble). See, inter alia, W. Hammerschick, C. Morgenstern, S. Bikelis, M. Boone, I. Durnescu et al., DETOUR, op. cit., pp. 66-68.

101 See E. Sellier and A. Weyembergh, Criminal procedural laws across the European UnionA comparative analysis of selected main differences and the impact they have over the development of EU legislation, (Brussels: Parliament, 2018) p. 87.

102 In AlChodor, the Court dismissed the use of grounds for detention not specified in legislation and only in case law - this being contrary to ECHR case law where the concept of legal basis includes also case law: Judgment of 15 March 2017 (C-528/15, EU:C:2017:213, paragraph 40). 
First, it may be advisable to put forward different legal standards for pretrial detention on preventive grounds. After all, in light of the diversity of their purposes, it is questionable whether pre-trial detention on procedural grounds and pre-trial detention on preventive grounds should be subject to the same safeguards. What is more, if the ambiguity of concepts like 're-offending' and 'public order' cannot be ruled out completely, one needs at least a higher level of protection and stricter requirements for using detention on those grounds.

Second, it would be helpful to link the use of pre-trial detention with the threshold the custodial punishment potentially incurred by the suspect. This should be done in an effort to address the proportionality of detention. Such an initiative may have an impact on the functioning of certain instruments of judicial cooperation which should be better investigated.

Third, the obligation to seek and prefer alternatives should be further substantiated with clearer guidance about the content and the nature of such measures. There as well, one may need further guidance to ensure that the choice of alternatives is guided by the principle of proportionality.

Pre-trial detention remains a difficult puzzle to solve as it forms an amalgam of policy, judicial culture, organisation of national procedure and procedural rights. In our view, the way forward is to take a step back and reconsider its foundations. Better enforcement will not bring much if the legal standards are suffering from internal inconsistencies and fallacies; and exposing those was the aim of our contribution. One must reflect on the purposes of pre-trial detention, pondering how to ensure their achievement on the one hand, while respecting procedural rights on the other. Current practice shows inconsistency within the most prevalent legal standards, which in our view needs to be urgently repaired.

\section{Acknowledgements}

The article has been conceived and drafted together; Adriano Martufi is the main author of sections 1., 3.2 and 3.3. and Christina Peristeridou is main author of sections 2, 2.1, 2.2. The other sections have been co-authored. 